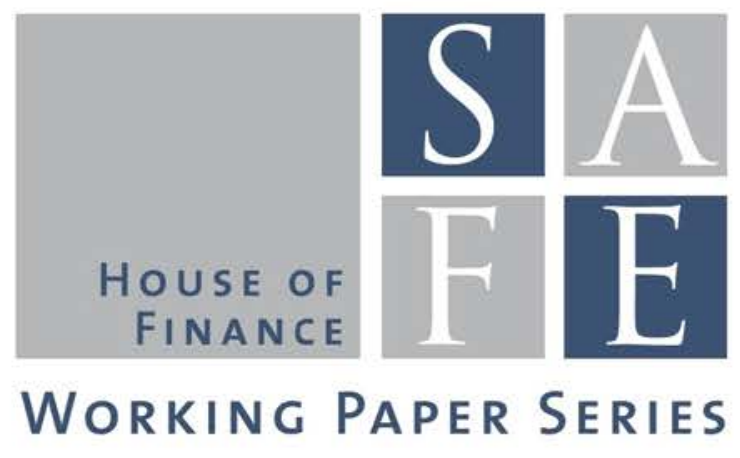

Baptiste Massenot - Yuri Pettinicchi

\title{
Can Households See into the Future? Survey Evidence from the Netherlands
}

SAFE Working Paper No. 233

\section{SAFE I Sustainable Architecture for Finance in Europe}

A cooperation of the Center for Financial Studies and Goethe University Frankfurt 


\title{
Can Households See into the Future? Survey Evidence from the Netherlands*
}

\author{
Baptiste Massenot $^{\dagger}$ Yuri Pettinicchi ${ }^{\ddagger}$
}

July 14, 2018

\begin{abstract}
This paper presents new evidence on the expectation formation process from a Dutch household survey. Households become too optimistic about their future income after their income has improved, consistent with the over-extrapolation of their experience. We show that this effect of experience is persistent and that households over-extrapolate income losses more than income gains. Furthermore, older households over-extrapolate more, suggesting that they did not learn over time to form more accurate expectations. Finally, we study the relationship between expectation errors and consumption. We find that more over-optimistic households intend to consume more and subsequently report higher consumption, even though they do not consume as much as they intended to. These results suggests that overextrapolation hurts consumers and amplify business cycles.
\end{abstract}

${ }^{*}$ We gratefully acknowledge research support from the Research Center SAFE, funded by the State of Hessen initiative for research LOEWE. Yuri Pettinicchi gratefully acknowledges funding received from the 7.FP, COFUND, Goethe International Postdoc Programme GO-IN, No. 291776. We thank participants at the workshop "Household Surveys in Macroeconomics" in Hamburg, the MEA seminar in Munich, and the workshop "Firm and Household Uncertainty, Expectation Formation, and Macroeconomic Implications" in Kiel.

${ }^{\dagger}$ Goethe University Frankfurt - SAFE, E-mail: massenot@safe.uni-frankfurt.de.

${ }^{\ddagger}$ Max Planck Institute for Social Law and Social Policy, E-mail: pettinicchi@mea.mpisoc.mpg.de. 


\section{Introduction}

This paper presents new evidence on the expectation formation process of households. It focuses on the expectation about the evolution of their personal financial situation, a variable that enters the widely followed consumer confidence index and that is an important determinant of consumption-saving decisions. Macroeconomics typically assumes that households form rational expectations about their future income, but little is known about how these expectations are formed. In this paper, we study the role of personal experience on expectation formation, a relationship that has been widely documented in other economic domains but that has received less attention in the case of household income. Furthermore, we study the link between expectation formation and consumption. Consumers may indeed be particularly hurt by expectation errors if these are followed by consumption changes. This could also have important consequences for the amplification of business cycles. For example, a recovery can be delayed if households become overpessimistic during a downturn and spend less as a result.

To study these questions, we use a survey of Dutch households conducted quarterly from 2009 to 2014. The survey includes questions on expected and realized income. An important advantage of this survey is that we observe the same households several times, which allows us to compute their expectation errors. Figure 1 shows the evolution of expected and realized financial situation. A striking observation in our view is that these two variables closely follow each other. First, it suggests that households have a limited ability to forecast their future income. Otherwise, we would observe that expected financial situation leads realized financial situation by the forecasting horizon, which is 1 year here. Second, it suggests that households make predictable forecast errors. For example, households become too optimistic following an improvement in their financial situation.

To further examine these conjectures, we compute for each household a measure of expectation error by taking the difference between their expected financial situation and their future realized financial situation. Figure 2 shows the evolution of these expectation errors. House- 


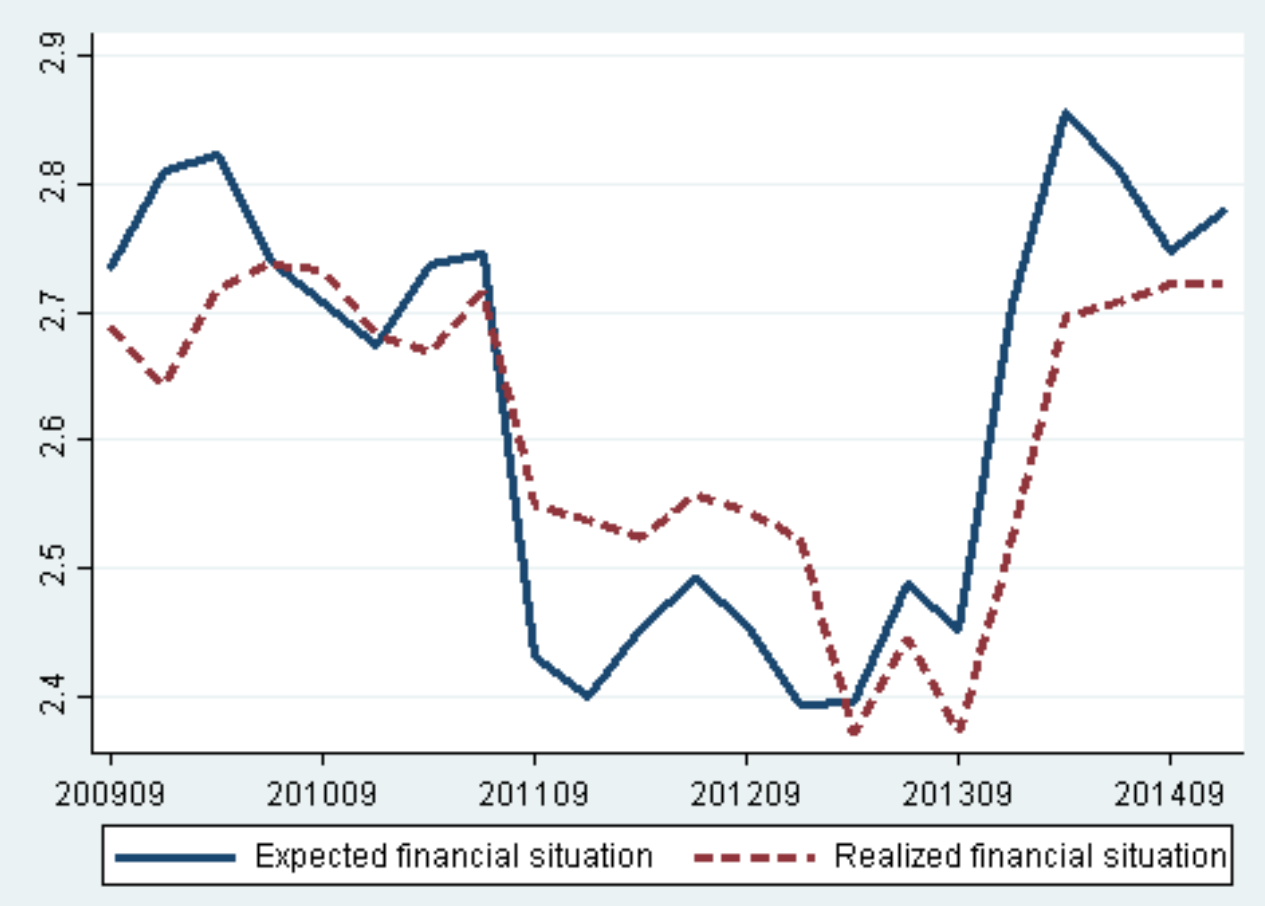

Figure 1: Evolution of expected financial situation over the next year and realized financial situation over the past year. Both variables range from 1 to 5 , where a higher value indicates a larger improvement in the financial situation. See section 2 for further details.

holds are sometimes too optimistic and sometimes too pessimistic and they do not seem to make expectation errors on average. When analyzing the individual data, we find that expectation errors are positively correlated with past financial situation. This confirms that households extrapolate their experience too much and make predictable forecasting errors. We also observe that households extrapolate improvements in their financial situation more than deteriorations and that experience has a persistent effect on expectation errors.

Households may learn over time to reduce their extrapolation bias. We find instead that older households over-extrapolate more. A 50 year-old has an extrapolation bias that is about $50 \%$ larger than the one of a 30-year old. We both expect and find that more educated households have a smaller extrapolation bias. The extrapolation bias of households with primary education is three times larger than households with college education. Finally, we find that the extrapolation bias does not depend on income or on gender.

In the second part of the paper, we study the link between expectation errors and consump- 


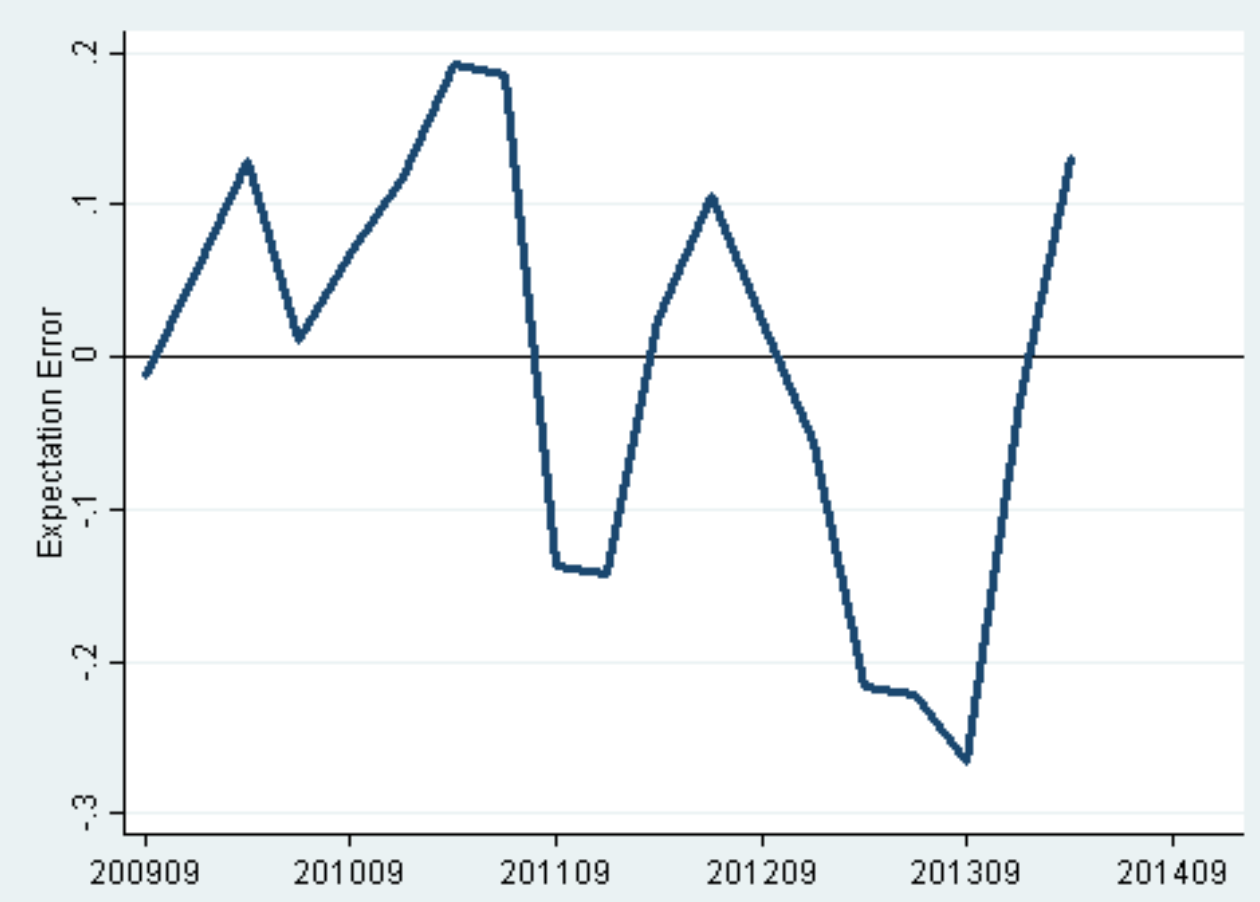

Figure 2: Evolution of expectation errors, computed as the difference between expected financial situation and future realized financial situation. See section 2 for further details.

tion. We expect that a household who is too optimistic about his financial situation consumes more than if he had formed the correct expectation. We use several questions from the survey that ask households to report how much they intend to consume and how much they consumed a broad range of consumption items. We find that more overoptimistic households intend to consume more and subsequently consume more. Finally, we also find that more overoptimistic households more often consume less than they intended to. These results suggest that overextrapolation impairs the ability of households to smooth their consumption and thus decreases their welfare. It could also have implications for business cycles. If many households become too optimistic, for example, they may consume more and thus increase aggregate demand.

Our paper is related to the empirical literature studying expectations using survey data (Manski, 2004; Pesaran and Weale, 2006). A large strand of the literature studies whether household expectations about their future income or consumer sentiment can predict consumer spending (Acemoglu and Scott, 1994; Carroll et al., 1994; Souleles, 2004; Ludvigson, 2004; Brown et al., 
2005). Using the same data as we do, Bissonnette and Van Soest (2015) study whether the perception about the financial crisis predicts expectation errors and Christelis et al. (2016) study the effect of income expectations on precautionary savings. Finally, Ekici and Koydemir (2016) and Barazzetta (2015) use a British survey and show that more over-optimistic households tend to report lower happiness. Survey data on expectations has also been used to discriminate between different models of expectation formation under imperfect information (Coibion and Gorodnichenko, 2012; Andrade and Le Bihan, 2013; Coibion and Gorodnichenko, 2015; Coibion et al., 2015).

We contribute to the growing body of evidence supporting over-extrapolative expectations. The evidence comes from laboratory experiments (Haruvy et al., 2007; Asparouhova et al., 2009; Hommes et al., 2008; Beshears et al., 2013; Frydman and Nave, 2016) or survey data (Tortorice, 2012; Greenwood and Shleifer, 2014; Gennaioli et al., 2015; Massenot and Pettinicchi, 2018). Our work is also in line with the growing evidence that experience plays a crucial role on economic behavior through its effect on expectations (Barberis et al., 1998; Vissing-Jorgensen, 2004; Piazzesi and Schneider, 2009; Malmendier and Nagel, 2011). Finally, the literature on behavioral economics proposes several foundations for extrapolative biases (Tversky and Kahneman, 1974; Gilovich et al., 1985; Rabin, 2002; Rabin and Vayanos, 2010).

Das and van Soest (1999) and Rozsypal and Schlafmann (2017) also present evidence consistent with the over-extrapolation of income by households. Das and van Soest (1999) use an earlier survey of Dutch households and develop a new estimator to deal with ordered variables in panel data, which we also use when studying the robustness of our results. Rozsypal and Schlafmann (2017) use a survey of US households and show how integrating over-extrapolation in a macro model both improves its quantitative fit and yields novel policy implications. Compared to these references, we present new results on over-extrapolation. We study its persistence, its asymmetry, and how it depends on household characteristics. Furthermore, we uncover a link between over-extrapolation and consumption, which has interesting implications for the econ- 
omy and welfare.

The paper is organized as follows. Section 2 presents the data. Section 3 shows the results on over-extrapolation. Section 4 studies the relationship between expectation errors and consumption. Section 5 concludes.

\section{Data}

We use a representative survey of Dutch households, the Tilburg Consumer Outlook Monitor, ${ }^{1}$ that tracked consumption and sentiment from September 2009 to December 2014 on a quarterly basis (22 quarters). About 1400 households participated to the survey each quarter, which gives us a total of about 33,000 observations. ${ }^{2}$ We observe the same household on average 8 times.

The two main questions of interest are past and expected changes in financial situation, which we refer to as past and expected income for short:

- Past income. Has the financial situation of your household gotten better or worse over the past 12 months? (1 Clearly gotten worse; 2 gotten a bit worse; 3 stayed the same; 4 gotten a bit better; 5 clearly gotten better; - I don't know.)

- Expected income. How do you think the financial situation of your household will develop over the coming 12 months? (1 Clearly get worse; 2 get a bit worse; 3 stay the same; 4 get a bit better; 5 clearly get better; - I don't know.)

On average, less than $4 \%$ of the participants chose the "I don't know" option.

The next variable of interest is the expectation error $e_{t}$ which we compute by taking the difference between expected income in quarter $t$ and past income one year later $x_{t+4}$, that is, $e_{t}=y_{t}-x_{t+4}$. We use $x_{t+3}$ when $x_{t+4}$ is not available, and $x_{t+5}$ when neither $x_{t+3}$ nor $x_{t+4}$ are available. The resulting measure ranges from -4 to 4 . A positive error means over-optimism and a negative error over-pessimism.

\footnotetext{
${ }^{1}$ The data can be accessed here: https: / / www. lissdata.nl/access-data

${ }^{2}$ In some rare cases, two members of the same household participated to the survey. In those cases, we only keep the head of the household.
} 
Table 1 summarizes the distributions of household expectations and expectation errors. From the initial 33,000 observations, we obtain about 24,000 expectation errors. On average, both past and expected financial situation slightly deteriorate and households do not make expectation errors.

Table 1: Summary statistics

\begin{tabular}{lrrrrr}
\hline Variable & Mean & Std Dev & Min & Max & $\mathbf{N}$ \\
\hline Exp Income & 2.6 & .868 & 1 & 5 & 32792 \\
Past Income & 2.6 & .842 & 1 & 5 & 33128 \\
Exp Error & -.010 & .885 & -4 & 4 & 24484 \\
\hline
\end{tabular}

Table 2 summarizes the distributions of households' characteristics for the expectations sample and the expectation errors sample. We look at gender, age, whether the households attended high school or college, and gross income in Euros. The two samples are comparable in terms of these observable characteristics.

Table 2: Summary statistics - Household Characteristics

\begin{tabular}{lcccc}
\hline & \multicolumn{2}{c}{ Expectations Sample } & \multicolumn{2}{c}{ Exp Errors Sample } \\
\hline Variable & Mean & Std Dev & Mean & Std Dev \\
\hline Female & 0.30 & 0.46 & 0.29 & 0.45 \\
Age & 55 & 15 & 55.5 & 15 \\
High School & 0.34 & 0.47 & 0.34 & 0.47 \\
College & 0.11 & 0.31 & 0.10 & 0.30 \\
Income & 3830 & 7571 & 3845 & 7957 \\
\hline
\end{tabular}

\section{Over-Extrapolation?}

Framework We first illustrate the concepts of extrapolation and over-extrapolation in the simple case where the income growth $y$ of households follows an AR(1) process

$$
y^{\prime}=\alpha y+\epsilon,
$$

where $y^{\prime}$ refers to future income growth, $\alpha$ is a parameter, and $\epsilon$ is a white noise. 
Table 3: Individual experience

\begin{tabular}{lcccc}
\hline & $(1)$ & $(2)$ & $(3)$ & $(4)$ \\
VARIABLES & Exp Income & Exp Error & Exp Income & Exp Error \\
\hline \multirow{3}{*}{ Past Income } & $0.326^{* * *}$ & $0.348^{* * *}$ & $0.300^{* * *}$ & $0.324^{* * *}$ \\
& $(0.00956)$ & $(0.0125)$ & $(0.00949)$ & $(0.0125)$ \\
Constant & $1.777^{* * *}$ & $-0.903^{* * *}$ & $1.905^{* * *}$ & $-0.885^{* * *}$ \\
& $(0.0249)$ & $(0.0321)$ & $(0.0327)$ & $(0.0433)$ \\
Observations & 32,735 & 24,446 & 32,735 & 24,446 \\
R-squared & 0.106 & 0.072 & 0.147 & 0.092 \\
IND FE & YES & YES & YES & YES \\
TIME FE & NO & NO & YES & YES \\
\hline \multicolumn{5}{c}{ Robust standard errors in parentheses } \\
& $* * * \mathrm{p}<0.01,{ }^{* *} \mathrm{p}<0.05,{ }^{*} \mathrm{p}<0.1$ &
\end{tabular}

Households forecast

$$
y^{f}=\beta y .
$$

Their average expectation error is

$$
y^{f}-y^{\prime}=\gamma y,
$$

where $\gamma=\beta-\alpha$.

We are interested in estimating the relationships (1) and (2). If $\beta$ is positive, households extrapolate their recent experience and consider shocks to have some persistence. If $\beta$ is negative, then households mean-revert and they consider shocks to be short-lived.

If $\gamma$ is positive, households over-extrapolate. They consider shocks to be more persistent than they actually are. Following a positive shock to their income, households expect their income to keep increasing. By contrast, if $\gamma$ is negative, households mean-revert too much. Finally, If $\gamma=0$, households form unbiased forecasts.

Baseline We first regress expectations and expectation errors on past income. We use a fixed effects estimator to control for household-specific characteristics. Standard errors are clustered at the household level. The Appendix shows that the results are robust to alternative estimators.

Column (1) of Table 3 shows that households are more optimistic about their financial situ- 
ation when their financial situation improved more in the previous year. This result is highly significant. This suggests that households consider shocks to their income to be persistent.

Column (2) shows that expectation errors are positively correlated with past changes in financial situation. Again this result is significant. This suggests that households exaggerate the persistence of the shocks and over-extrapolate. They become too optimistic when their financial situation has improved and too pessimistic when it has deteriorated.

Columns (3) and (4) show that these first two results are robust to the inclusion of quarter fixed effects that control for aggregate shocks.

Persistence We now study whether past income has persistent effects on expectations. Compared to the previous specification, we further control for the fourth lag of past income. That is, we look at the effect of a change in the financial situation over the previous year as well as two years ago on expectations. If a change in financial situation experienced further in the past has an impact on expectations, this implies that households extrapolate more strongly a streak of similar experience and thus that households make larger mistakes. This also implies that when faced with a reversal, households will take longer to recognize this break.

Column (1) of Table 4 shows that households do not extrapolate a change in income that occurred two years ago. Instead they tend to mean revert indicating that they consider shocks to their financial situation to start mean reverting after 1 year. However, column (2) suggests that they do not mean-revert enough since the lag of past income is positively and significantly associated with expectation errors. This result suggests that two years after a shock, households still extrapolate too much. Since past income retains its significance, the results also suggest that households make larger mistakes following a longer trend.

Asymmetry Next, we study whether households react asymmetrically to positive and negative experience. We run a similar set of regressions but allow for the effect of positive and negative changes in financial situation to be different. We now control for four indicator variables that 
Table 4: Individual experience - persistence and asymmetry

\begin{tabular}{|c|c|c|c|c|}
\hline VARIABLES & $\begin{array}{c}(1) \\
\text { Exp Income }\end{array}$ & $\begin{array}{c}(2) \\
\text { Exp Error }\end{array}$ & $\begin{array}{c}\text { (3) } \\
\text { Exp Income }\end{array}$ & $\begin{array}{c}(4) \\
\text { Exp Error }\end{array}$ \\
\hline Past Income & $\begin{array}{l}0.315^{* * *} \\
(0.0164)\end{array}$ & $\begin{array}{l}0.400^{* * * *} \\
(0.0228)\end{array}$ & & \\
\hline Lag Past Income & $\begin{array}{c}-0.0287^{* *} \\
(0.0130)\end{array}$ & $\begin{array}{l}0.0434^{* *} \\
(0.0196)\end{array}$ & & \\
\hline Lot worse & & & $\begin{array}{c}-0.602^{* * *} \\
(0.0266)\end{array}$ & $\begin{array}{c}-0.667^{* * *} \\
(0.0363)\end{array}$ \\
\hline Bit worse & & & $\begin{array}{c}-0.296^{* * *} \\
(0.0117)\end{array}$ & $\begin{array}{c}-0.339^{* * * *} \\
(0.0162)\end{array}$ \\
\hline Bit better & & & $\begin{array}{l}0.359^{* * *} \\
(0.0186)\end{array}$ & $\begin{array}{l}0.370^{* * *} \\
(0.0276)\end{array}$ \\
\hline Lot better & & & $\begin{array}{l}0.435^{* * *} \\
(0.0568)\end{array}$ & $\begin{array}{l}0.376^{* * *} \\
(0.0778)\end{array}$ \\
\hline Constant & $\begin{array}{l}1.846^{* * *} \\
(0.0715)\end{array}$ & $\begin{array}{c}-1.146^{* * *} \\
(0.0810)\end{array}$ & $\begin{array}{l}2.801^{* * *} \\
(0.0220)\end{array}$ & $\begin{array}{c}0.0933^{* * *} \\
(0.0288)\end{array}$ \\
\hline Observations & 10,545 & 7,737 & 32,735 & 24,446 \\
\hline R-squared & 0.165 & 0.122 & 0.149 & 0.093 \\
\hline IND FE & YES & YES & YES & YES \\
\hline TIME FE & YES & YES & YES & YES \\
\hline
\end{tabular}

correspond to the possible evolution of past income: a lot worse, a bit worse, a bit better and a lot better. The omitted category is "stay the same".

Column (3) of Table 4 shows that households extrapolate negative events more than positive ones, suggesting that households perceive negative shocks to their income to be more persistent than positive shocks. This result is driven by large changes in financial situation as small changes have similar coefficients in absolute value.

Column (4) shows that expectation errors also react asymmetrically to positive and negative past income. Again, this result is driven by large changes. This implies that households make larger mistakes following negative shock than following a positive shock.

A potential limitation of these results on the asymmetry of over-extrapolation is that we use categorical data and it may not fully reflect quantitative changes in the financial situation of households. For example, the categorical classification may not fully capture a situation where 


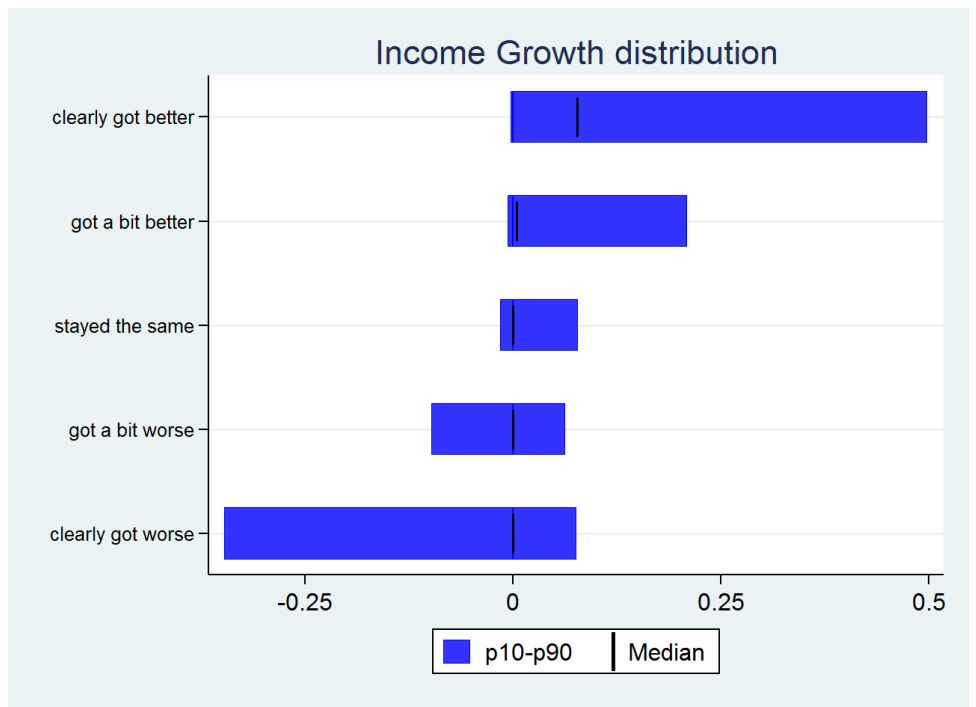

Figure 3: Realized financial situation and income growth.

negative shocks to income growth are on average larger than positive shocks. Since households also report their income, we can compute a quantitative measure of income growth and investigate the presence of asymmetric patterns. Figure 3 shows the distribution of income growth for each reported change in financial situation. Although, the relationship is noisy, the quantitative income growth variable is partially correlated with the realized financial situation variable and households who report an improved financial situation experienced a larger absolute income growth than households who report a worse financial situation. To mechanically explain our results that households over-extrapolate negative shocks more than positive shocks, the opposite would have to be true. Thus, this gives us additional confidence that over-extrapolation is stronger for negative shocks than for positive shocks.

These results support the idea that individuals may suffer asymmetric losses when forming expectations (Elliott et al., 2008). Households may indeed prefer to be a bit too conservative to avoid disappointment. Following an improving financial situation, they become more optimistic but not too much to avoid disappointment. Our results suggest that disappointment aversion is not so strong that it overcomes the tendency to over-extrapolate. Following a negative shock, households become more pessimistic not only because they expect the shock to be persistent but also because they want to avoid disappointment. These results can have consequences on the 
documented asymmetry of business cycles (Neftci, 1984; Sichel, 1993; McKay and Reis, 2008). If households become more pessimistic following a negative shock than they become optimistic following a positive shock, then busts will be steeper than booms.

Household characteristics We now investigate whether the extrapolation bias depends on household characteristics. In particular, older households have more experience and may have learned over time to over-extrapolate less. Furthermore, more educated households may overextrapolate less. We should thus expect a smaller over-extrapolation coefficient for older and more educated households. This would imply that when we regress expectation errors on the interaction between past income and age or education, the overall coefficient on past income should be closer to 0 for older and more educated households. We also investigate whether the extrapolation bias depends on income or gender, though we do not have a prior hypothesis.

We regress expectations and expectation errors on past income, age, education, gender, income, and also interact each household characteristic with past income. Since the characteristics of households changed very little or not at all, we do not include household fixed effects. Table 5 shows the results.

We find that older households over-extrapolate more. The effect of past income on expectation errors indeed increases with age. This suggests that individuals do not learn how to overextrapolate less over time. According to the estimates, a 50-year old individual has an extrapolation bias that is about $50 \%$ higher than a 30 -year old one. We also checked for the presence of non-linear effects of age but did not find any (results not reported).

Second, we look at the impact of education on expectation errors. Households report their education level: primary school (1), middle school (2), high school (3), middle vocational school (4), high vocational school (5), and College (6). Consistent with our hypothesis, we find that more educated households over-extrapolate less. A household with a primary education has an extrapolation bias that is about three times larger than a household who went to college.

Third, we study the effect of income on expectations. Households report their gross income, 
Table 5: Households Characteristics and Extrapolation Bias

\begin{tabular}{|c|c|c|c|c|}
\hline VARIABLES & $\begin{array}{c}(1) \\
\text { Exp Income }\end{array}$ & $\begin{array}{c}(2) \\
\text { Exp Error }\end{array}$ & $\begin{array}{c}(3) \\
\text { Exp Income }\end{array}$ & $\begin{array}{c}(4) \\
\text { Exp Error }\end{array}$ \\
\hline Past Income & $\begin{array}{l}0.516^{* * *} \\
(0.00656)\end{array}$ & $\begin{array}{l}0.124^{* * *} \\
(0.00858)\end{array}$ & $\begin{array}{l}0.509^{* * *} \\
(0.0348)\end{array}$ & $\begin{array}{l}0.110^{* *} \\
(0.0482)\end{array}$ \\
\hline Age & $\begin{array}{c}-0.00760^{* * *} \\
(0.000305)\end{array}$ & $\begin{array}{c}-0.00299^{* * *} \\
(0.000442)\end{array}$ & $\begin{array}{l}-0.0154^{* * *} \\
(0.00122)\end{array}$ & $\begin{array}{c}-0.00806^{* * *} \\
(0.00165)\end{array}$ \\
\hline Education & $\begin{array}{l}0.0245^{* * *} \\
(0.00306)\end{array}$ & $\begin{array}{l}-0.00585 \\
(0.00427)\end{array}$ & $\begin{array}{l}0.106^{* * *} \\
(0.0125)\end{array}$ & $\begin{array}{c}0.0576^{* * *} \\
(0.0163)\end{array}$ \\
\hline Female & $\begin{array}{l}-0.0298^{* * *} \\
(0.00992)\end{array}$ & $\begin{array}{l}-0.0111 \\
(0.0141)\end{array}$ & $\begin{array}{c}0.102^{* *} \\
(0.0395)\end{array}$ & $\begin{array}{l}-0.00297 \\
(0.0517)\end{array}$ \\
\hline Income & $\begin{array}{c}0.00887^{*} \\
(0.00455)\end{array}$ & $\begin{array}{l}-0.0235^{* * *} \\
(0.00640)\end{array}$ & $\begin{array}{c}0.0143 \\
(0.0182)\end{array}$ & $\begin{array}{l}-0.0342 \\
(0.0237)\end{array}$ \\
\hline Past Income*Age & & & $\begin{array}{l}0.00286^{* * *} \\
(0.000428)\end{array}$ & $\begin{array}{l}0.00189^{* * *} \\
(0.000596)\end{array}$ \\
\hline Past Income*Education & & & $\begin{array}{c}-0.0313^{* * *} \\
(0.00453)\end{array}$ & $\begin{array}{c}-0.0245^{* * *} \\
(0.00604)\end{array}$ \\
\hline Past Income ${ }^{*}$ Female & & & $\begin{array}{c}-0.0513^{* * *} \\
(0.0143)\end{array}$ & $\begin{array}{l}-0.00319 \\
(0.0194)\end{array}$ \\
\hline Past Income ${ }^{*}$ Income & & & $\begin{array}{l}-0.00283 \\
(0.00649)\end{array}$ & $\begin{array}{c}0.00373 \\
(0.00868)\end{array}$ \\
\hline Constant & $\begin{array}{l}1.641^{* * *} \\
(0.0391)\end{array}$ & $\begin{array}{l}-0.0975^{*} \\
(0.0523)\end{array}$ & $\begin{array}{l}1.692^{* * *} \\
(0.101)\end{array}$ & $\begin{array}{l}-0.0409 \\
(0.135)\end{array}$ \\
\hline Observations & 28,540 & 21,502 & 28,540 & 21,502 \\
\hline R-squared & 0.336 & 0.042 & 0.341 & 0.044 \\
\hline IND FE & $\mathrm{NO}$ & $\mathrm{NO}$ & $\mathrm{NO}$ & $\mathrm{NO}$ \\
\hline TIME FE & YES & YES & YES & YES \\
\hline
\end{tabular}

which we categorize in quartiles. It is not clear how the extrapolation bias should depend on income. We find that income does not affect the extrapolation bias.

Finally, we investigate whether men and women differ in their expectation formation process and find that the extrapolation bias does not depend on gender.

\section{Are expectation errors costly?}

Over-extrapolation may hurt households and amplify economic fluctuations if expectation errors are followed by consumption changes. Following an improvement in their financial situation, 
for example, households become overoptimistic, that is, they expect their financial situation to improve more than it will. As a result, they may increase their consumption more than if they had not over-extrapolated. We find that more overoptimistic households intend to consume more (section 4.1) and subsequently consume more (section 4.2). We also show that overoptimistic households do not consume as much as they intended to (section 4.3), suggesting that in some cases households are able to recognize their overoptimism and correct their consumption path. Overall, these observations suggest that overextrapolation works against consumption smoothing and thus decreases welfare.

To study these questions, we regress several measures of consumption on expectation errors. One issue that may arise is that, by construction, more over-optimistic households are also more likely to experience a deteriorating financial situation. As a result, we will not be able to tell whether the change in consumption is due to the expectation error or to the new financial situation. Since it is difficult to separate between these two channels in the regression analysis, we only focus on households whose financial situation remained unchanged, which is the most frequent outcome. This restriction sharply decreases the sample size (we are only left with $20 \%$ of the observations) and eliminates most of the variation within households. We thus drop the household fixed effects and add several controls: income, gender, age, and education.

\subsection{Consumption Plans}

We first investigate the relationship between expectation errors and consumption plans. If households act on their expectations, we expect that more over-optimistic households should plan to consume more.

We use two sets of variables that measure consumption plans. First, households report the chance that they will buy different goods over the next year. The exact formulation of the question is as follows:

We now ask you to estimate, as well as you can, the chance that you will do one of 
these things in the future, in terms of a percentage between 0 and 100 percent. For example, if you are fully convinced that you will do one of these things, then you answer with 100 percent. If, on the other hand, there is a small chance that you might not do it, then you answer with 97 percent or less. If you are fully convinced that you will not do one of these things, then you indicate 0 percent. But if there is a small chance that you might do it, then you indicate 3 percent or more. And if you think that the chance is actually just as good as not, then you answer with 50 percent, or slightly more or slightly less if that seems more appropriate to how you feel. How much chance is there that you or someone in your household will, in the coming 12 months...

- buy a house or have a house built?

- buy a new car (not second-hand or used)?

- buy new big appliances, such as a washing machine or television?

- buy new big interior objects, such as furniture?

- take a long holiday (more than eight days consecutively)?

- take a short holiday (two to seven days consecutively)?

We then regress the measures of consumption plans on expectation errors. Both the consumption plan and the expectation used to compute the expectation error are reported in the same quarter. We control for time fixed effects. Table 6 shows that more over-optimistic households report a significantly higher chance to consume each of these consumption items, with the exception of a house.

Second, we use an additional set of variables that also measure consumption plans but cover different consumption items and are formulated slightly differently. Households report whether they intend in the coming six months to consume more or less clothing, restaurant meals, and entertainment compared to today. The exact formulation is as follows: 
Table 6: Consumption Plans and Expectation Errors.

\begin{tabular}{lcccccc}
\hline \multirow{2}{*}{ VARIABLES } & $(1)$ & $(2)$ & $(3)$ & $(4)$ & $(5)$ & $(6)$ \\
& House & Car & Appliance & Furniture & Short Holiday & Long Holiday \\
\hline \multirow{2}{*}{ Exp Error } & 0.283 & $1.571^{* * *}$ & $1.708^{* * *}$ & $2.589^{* * *}$ & $3.964^{* * *}$ & $5.209^{* * *}$ \\
& $(0.340)$ & $(0.436)$ & $(0.577)$ & $(0.555)$ & $(0.908)$ & $(0.853)$ \\
Constant & $10.86^{* * *}$ & $3.740^{*}$ & $21.97^{* * *}$ & $19.76^{* * *}$ & $18.25^{* * *}$ & 0.847 \\
& $(1.951)$ & $(1.912)$ & $(3.148)$ & $(2.893)$ & $(5.306)$ & $(4.893)$ \\
Observations & 4,522 & 4,522 & 4,522 & 4,522 & 4,522 & 4,522 \\
R-squared & 0.023 & 0.022 & 0.034 & 0.068 & 0.197 & 0.193 \\
IND FE & NO & NO & NO & NO & NO & NO \\
TIME FE & YES & YES & YES & YES & YES & YES \\
\hline
\end{tabular}

${ }_{* * *} \mathrm{p}<0.01,{ }^{* *} \mathrm{p}<0.05,{ }^{*} \mathrm{p}<0.1$. We control for income, gender, age, and education in all specifications. Robust standard errors in parentheses. Consumption plans are reported at quarter q, Expectation Error is the difference between expected income reported at quarter $\mathrm{q}$ and realized income reported at quarter $\mathrm{q}+4$.

Of the things listed below, please indicate whether you intend, in the coming six months, to do so less or more than you do at present. Compared to what I do now, over the next six months I intend to... (1 much less so; 2 less so; 3 a bit less so; 4 just as much; 5 a bit more so; 6 more so; 7 much more so)

- spend money on clothing and clothing accessories.

- spend money on eating out in restaurants.

- spend money on leisure (such as visiting the cinema and performance acts) and on sports (including membership fees and materials).

Using the same specification as above, Table 7 shows that more over-optimistic households intend to consume significantly more than they do at present.

This first set of results suggests that the households who fail to correctly anticipate future changes in their financial situation also fail to make the appropriate consumption plans.

\subsection{Actual Consumption}

Next, we want to know whether expectation errors are followed not only by intentions to change consumption but also by actual changes in consumption. In this section, we look at the rela- 
Table 7: Consumption Plans and Expectation Errors

\begin{tabular}{lccc}
\hline VARIABLES & $\begin{array}{c}(1) \\
\text { Clothing }\end{array}$ & $\begin{array}{c}(2) \\
\text { Restaurant }\end{array}$ & $\begin{array}{c}(3) \\
\text { Leisure }\end{array}$ \\
\hline Exp Error & $0.279^{* * *}$ & $0.349^{* * *}$ & $0.307^{* * *}$ \\
& $(0.0227)$ & $(0.0245)$ & $(0.0239)$ \\
Constant & $3.270^{* * *}$ & $2.867^{* * *}$ & $3.095^{* * *}$ \\
& $(0.110)$ & $(0.128)$ & $(0.121)$ \\
& & & \\
Observations & 4,520 & 4,520 & 4,520 \\
R-squared & 0.109 & 0.153 & 0.176 \\
IND FE & NO & NO & NO \\
TIME FE & YES & YES & YES \\
\hline
\end{tabular}

${ }^{* * *} \mathrm{p}<0.01,{ }^{* *} \mathrm{p}<0.05,{ }^{*} \mathrm{p}<0.1$. We control for income, gender, age, and education in all specifications. Robust standard errors in parentheses. Consumption plans are reported at quarter q, Expectation Error is the difference between expected income reported at quarter $\mathrm{q}$ and realized income reported at quarter $\mathrm{q}+4$.

tionship between expectation errors and two measures of consumption. Note that actual consumption is reported at quarter $\mathrm{q}$ while the expectation used to compute the expectation error is reported at q-4 (therefore referred to as "Lag Exp Error" in the tables).

In the first measure of actual consumption, households report whether they bought different consumption goods over the past year. The exact formulation of the question is as follows:

In the past 12 months (calculated back from today), did you or someone in your household... (yes; no)

- buy a house or have a house built?

- buy a new car (not second-hand or used)?

- buy new big appliances, such as a washing machine or television?

- buy new big interior objects, such as furniture?

- take a long holiday (more than eight days consecutively)?

- take a short holiday (two to seven days consecutively)?

To make this variable comparable with the consumption plan, we code it as 100 if households answer yes to these questions and 0 if they answer no. 
Table 8: Actual Consumption and Expectation Errors

\begin{tabular}{lcccccc}
\hline \multirow{2}{*}{ VARIABLES } & $(1)$ & $(2)$ & $(3)$ & $(4)$ & $(5)$ & $(6)$ \\
& House & Car & Appliance & Furniture & Short Holiday & Long Holiday \\
\hline \multirow{2}{*}{ Lag Exp Error } & $0.858^{* *}$ & 0.426 & -1.323 & 0.349 & 1.710 & $2.839^{* * *}$ \\
& $(0.387)$ & $(0.628)$ & $(0.920)$ & $(0.792)$ & $(1.055)$ & $(1.082)$ \\
Constant & $8.482^{* * *}$ & 3.984 & $23.47^{* * *}$ & $19.77^{* * *}$ & $22.44^{* * *}$ & $35.46^{* * *}$ \\
& $(2.249)$ & $(3.010)$ & $(4.953)$ & $(4.371)$ & $(6.289)$ & $(6.401)$ \\
Observations & 4,505 & 4,505 & 4,505 & 4,505 & 4,505 & 4,505 \\
R-squared & 0.022 & 0.020 & 0.015 & 0.036 & 0.159 & 0.092 \\
IND FE & NO & NO & NO & NO & NO & NO \\
TIME FE & YES & YES & YES & YES & YES & YES \\
\hline
\end{tabular}

${ }^{* * *} \mathrm{p}<0.01,{ }^{* *} \mathrm{p}<0.05,{ }^{*} \mathrm{p}<0.1$. We control for income, gender, age, and education in all specifications. Robust standard errors in parentheses. Actual consumption is reported at quarter q, Lag Expectation Error is the difference between expected income reported at quarter q-4 and realized income reported at quarter $\mathrm{q}$.

We then look at the relationship between these measures of actual consumption and past expectation errors. We control for time fixed effects. Table 8 shows that more over-optimistic households subsequently report a higher consumption, except appliances. However, the effect of past expectation errors on consumption is only statistically significant for housing and long holidays.

The second measure of actual consumption covers additional consumption items and is formulated slightly differently. Households report whether, over the last 6 months, they consumed more or less clothing, restaurant meals, and entertainment compared to before. The exact formulation is as follows:

Please indicate for each item whether, over the last six months, you did them more or did them less, compared to what you did before. Compared to what I did before, in the last six months I... (1 much less so; 2 less so; 3 a bit less so; 4 just as much; 5 a bit more so; 6 more so; 7 much more so)

- spend money on clothing and clothing accessories.

- spend money on eating out in restaurants. 
Table 9: Reported Consumption and Expectation Errors

\begin{tabular}{lccc}
\hline VARIABLES & $\begin{array}{c}(1) \\
\text { Clothing }\end{array}$ & $\begin{array}{c}(2) \\
\text { Restaurant }\end{array}$ & $\begin{array}{c}(3) \\
\text { Leisure }\end{array}$ \\
\hline Lag Exp Error & $0.127^{* * *}$ & $0.203^{* * *}$ & $0.154^{* * *}$ \\
& $(0.0228)$ & $(0.0255)$ & $(0.0235)$ \\
Constant & $3.518^{* * *}$ & $3.165^{* * *}$ & $3.419^{* * *}$ \\
& $(0.113)$ & $(0.141)$ & $(0.134)$ \\
& & & \\
Observations & 4,503 & 4,503 & 4,503 \\
R-squared & 0.057 & 0.103 & 0.114 \\
IND FE & NO & NO & NO \\
TIME FE & YES & YES & YES \\
\hline
\end{tabular}

${ }^{* * *} \mathrm{p}<0.01,{ }^{* *} \mathrm{p}<0.05,{ }^{*} \mathrm{p}<0.1$. We control for income, gender, age, and education in all specifications. Robust standard errors in parentheses. Actual consumption is reported at quarter q, Lag Expectation Error is the difference between expected income reported at quarter q-4 and realized income reported at quarter q.

- spend money on leisure (such as visiting the cinema and performance acts) and on sports (including membership fees and materials).

Using the same specification as above, Table 9 shows that more over-optimistic households consume significantly more than they used to.

These results suggest that more over-optimistic households not only intend to consume more but also often follow up on their intention. This suggests that expectation errors are costly because they prevent households from smoothing their consumption.

\subsection{Consumption Surprises}

Next, we want to examine whether households adjust their consumption plans when they make expectation errors. An over-optimistic household, for example, may not consume as much as he intended to once he realizes that his financial situation is not as good as he expected.

We compute consumption surprises by taking the difference between consumption plan and future reported consumption, by using the consumption measures described in the two previous sections on house, cars, etc. A higher value implies that the household was too optimistic concerning his consumption level, that is, he expected to consume more than he actually did. 
Table 10: Consumption Surprises and Expectation Errors

\begin{tabular}{|c|c|c|c|c|c|c|}
\hline VARIABLES & $\begin{array}{c}(1) \\
\text { House }\end{array}$ & $\begin{array}{l}(2) \\
\text { Car }\end{array}$ & $\begin{array}{c}(3) \\
\text { Appliance }\end{array}$ & $\begin{array}{c}(4) \\
\text { Furniture }\end{array}$ & $\begin{array}{c}(5) \\
\text { Short Holiday }\end{array}$ & $\begin{array}{c}(6) \\
\text { Long Holiday }\end{array}$ \\
\hline Exp Error & $\begin{array}{c}-0.542 \\
(0.475)\end{array}$ & $\begin{array}{c}0.978 \\
(0.651)\end{array}$ & $\begin{array}{c}3.122^{* * *} \\
(1.005)\end{array}$ & $\begin{array}{l}2.000^{* *} \\
(0.853)\end{array}$ & $\begin{array}{l}2.504^{* *} \\
(0.977)\end{array}$ & $\begin{array}{l}1.888^{* *} \\
(0.847)\end{array}$ \\
\hline Constant & $\begin{array}{c}2.546 \\
(2.172)\end{array}$ & $\begin{array}{l}-0.831 \\
(3.146)\end{array}$ & $\begin{array}{l}-1.036 \\
(5.261)\end{array}$ & $\begin{array}{l}0.0832 \\
(4.349)\end{array}$ & $\begin{array}{c}-36.42^{* * *} \\
(5.204)\end{array}$ & $\begin{array}{l}-7.513 \\
(4.902)\end{array}$ \\
\hline Observations & 4,522 & 4,522 & 4,522 & 4,522 & 4,522 & 4,522 \\
\hline R-squared & 0.006 & 0.010 & 0.007 & 0.005 & 0.051 & 0.011 \\
\hline IND FE & $\mathrm{NO}$ & $\mathrm{NO}$ & $\mathrm{NO}$ & $\mathrm{NO}$ & $\mathrm{NO}$ & $\mathrm{NO}$ \\
\hline TIME FE & YES & YES & YES & YES & YES & YES \\
\hline
\end{tabular}

We recode the actual consumption variables as 0 if the answer to the question was negative and 100 if the answer was positive. For each consumption item, we then take the difference between the consumption plan and the realized consumption reported one year later ( 3 quarters later if it is not available, or 5 quarters later if neither is available). The resulting variable gives a measure of consumption surprise. It can take any value between -100 and 100 . The average consumption surprise is close to zero and its mode is always zero. For more expensive items such as houses, households make almost no changes to their plans while for cheaper items such as a short holiday households revise their plans more often.

We then investigate how expectation errors are related to consumption surprises, where both the expected income and the consumption plan are reported at the same quarter q. As before, we focus on households whose financial situation remained unchanged as reported in quarter $\mathrm{q}+4$ and we drop the household fixed effects. Table 10 shows that more over-optimistic households are more likely to give up on their plan to consume a good, with the exception of housing and car.

This suggests that households who are wrong about their future financial situation are in 
some cases able to recognize their mistake and adjust their consumption.

\section{Conclusion}

This paper presents new evidence on the expectation formation process of households. It finds evidence consistent with over-extrapolation of recent experience. Households whose financial situation improved tend to become too optimistic. We also show that these expectation errors have implications on consumption choice and possibly on welfare. Over-optimistic households intend to consume more and subsequently consume more, even though they do not consume as much as they intended to. These results first suggest that over-extrapolation leads to excessive consumption volatility and potentially hurts consumers. Finally, over-extrapolation may have macroeconomic implications by amplifying fluctuations. For example, a crisis could be prolonged if many households become too pessimistic in a context of deteriorating financial situation. 


\section{References}

Acemoglu, D. and Scott, A. (1994). Consumer confidence and rational expectations: Are agents' beliefs consistent with the theory? The Economic Journal, 104(422):1-19.

Andrade, P. and Le Bihan, H. (2013). Inattentive professional forecasters. Journal of Monetary Economics, 60(8):967-982.

Asparouhova, E., Hertzel, M., and Lemmon, M. (2009). Inference from streaks in random outcomes: Experimental evidence on beliefs in regime shifting and the law of small numbers. Management Science, 55(11):1766-1782.

Baetschmann, G., Staub, K. E., and Winkelmann, R. (2015). Consistent estimation of the fixed effects ordered logit model. Journal of the Royal Statistical Society: Series A (Statistics in Society), 178(3):685-703.

Barazzetta, M. (2015). The asymmetric effect of expectations on subjective well-being. Working paper.

Barberis, N., Shleifer, A., and Vishny, R. (1998). A model of investor sentiment. Journal of financial economics, 49(3):307-343.

Beshears, J., Choi, J. J., Fuster, A., Laibson, D., Madrian, B. C., et al. (2013). What goes up must come down? experimental evidence on intuitive forecasting. American Economic Review, 103(3):570-74.

Bissonnette, L. and Van Soest, A. (2015). The financial crisis and consumers' income and pension expectations. Working paper.

Brown, S., Garino, G., Taylor, K., and Price, S. W. (2005). Debt and financial expectations: An individual-and household-level analysis. Economic Inquiry, 43(1):100-120.

Brüderl, J. and Ludwig, V. (2015). The SAGE handbook of regression analysis and causal inference, chapter Fixed-effects panel regression . doi: 10.4135/9781446288146.n15, pages 327-358. London: SAGE Publications Ltd.

Carroll, C. D., Fuhrer, J. C., and Wilcox, D. W. (1994). Does consumer sentiment forecast household spending? if so, why? The American Economic Review, 84(5):1397-1408.

Christelis, D., Georgarakos, D., Jappelli, T., and van Rooij, M. (2016). Consumption uncertainty and precautionary saving. Working paper.

Coibion, O. and Gorodnichenko, Y. (2012). What can survey forecasts tell us about information rigidities? Journal of Political Economy, 120(1):116-159.

Coibion, O. and Gorodnichenko, Y. (2015). Information rigidity and the expectations formation process: A simple framework and new facts. The American Economic Review, 105(8):2644-2678.

Coibion, O., Gorodnichenko, Y., and Kumar, S. (2015). How Do Firms Form Their Expectations? New Survey Evidence. Working paper.

Das, M. and van Soest, A. (1997). Expected and realized income changes: Evidence from the Dutch socio-economic panel. Journal of Economic Behavior E Organization, 32(1):137-154. 
Das, M. and van Soest, A. (1999). A panel data model for subjective information on household income growth. Journal of Economic Behavior E Organization, 40(4):409 - 426.

Ekici, T. and Koydemir, S. (2016). Income expectations and happiness: Evidence from british panel data. Applied Research in Quality of Life, 11(2):539-552.

Elliott, G., Komunjer, I., and Timmermann, A. (2008). Biases in macroeconomic forecasts: irrationality or asymmetric loss? Journal of the European Economic Association, 6(1):122-157.

Fernández-Val, I. and Weidner, M. (2016). "individual and time effects in nonlinear panel models with large $n, t$. Journal of Econometrics, 192(1):291 - 312.

Frydman, C. and Nave, G. (2016). Extrapolative beliefs in perceptual and economic decisions: Evidence of a common mechanism. Management Science.

Gennaioli, N., Ma, Y., and Shleifer, A. (2015). Expectations and investment. NBER Chapters.

Gilovich, T., Vallone, R., and Tversky, A. (1985). The hot hand in basketball: On the misperception of random sequences. Cognitive psychology, 17(3):295-314.

Greenwood, R. and Shleifer, A. (2014). Expectations of returns and expected returns. Review of Financial Studies, 27(3):714-746.

Haruvy, E., Lahav, Y., and Noussair, C. N. (2007). Traders' expectations in asset markets: experimental evidence. The American Economic Review, 97(5):1901-1920.

Hommes, C., Sonnemans, J., Tuinstra, J., and Van De Velden, H. (2008). Expectations and bubbles in asset pricing experiments. Journal of Economic Behavior \& Organization, 67(1):116-133.

Ludvigson, S. C. (2004). Consumer confidence and consumer spending. The Journal of Economic Perspectives, 18(2):29-50.

Malmendier, U. and Nagel, S. (2011). Depression babies: Do macroeconomic experiences affect risk taking? The Quarterly Journal of Economics, 126(1):373-416.

Manski, C. F. (2004). Measuring expectations. Econometrica, 72(5):1329-1376.

Massenot, B. and Pettinicchi, Y. (2018). Can Firms See into the Future? Survey Evidence from Germany. Journal of Economic Behavior and Organization, 145:66-79.

McKay, A. and Reis, R. (2008). The brevity and violence of contractions and expansions. Journal of Monetary Economics, 55(4):738-751.

Neftci, S. N. (1984). Are economic time series asymmetric over the business cycle? The Journal of Political Economy, 92(2):307-328.

Pesaran, M. H. and Smith, R. (1995). Estimating long-run relationships from dynamic heterogeneous panels. Journal of Econometrics, 68(1):79-113.

Pesaran, M. H. and Weale, M. (2006). Survey expectations. Handbook of economic forecasting, 1:715-776.

Piazzesi, M. and Schneider, M. (2009). Momentum traders in the housing market: Survey evidence and a search model. American Economic Review, 99(2):406-11. 
Rabin, M. (2002). Inference by believers in the law of small numbers. The Quarterly Journal of Economics, 117(3):775-816.

Rabin, M. and Vayanos, D. (2010). The gambler's and hot-hand fallacies: Theory and applications. The Review of Economic Studies, 77(2):730-778.

Rozsypal, F. and Schlafmann, K. (2017). Overpersistence bias in individual income expectations and its aggregate implications. Working paper.

Sichel, D. E. (1993). Business cycle asymmetry: a deeper look. Economic Inquiry, 31(2):224-236.

Souleles, N. S. (2004). Expectations, heterogeneous forecast errors, and consumption: Micro evidence from the michigan consumer sentiment surveys. Journal of Money, Credit and Banking, 36(1):39-72.

Tortorice, D. L. (2012). Unemployment expectations and the business cycle. The BE Journal of Macroeconomics, 12(1).

Tversky, A. and Kahneman, D. (1974). Judgment under uncertainty: Heuristics and biases. science, 185(4157):1124-1131.

Vissing-Jorgensen, A. (2004). Perspectives on behavioral finance: Does" irrationality" disappear with wealth? evidence from expectations and actions. In NBER Macroeconomics Annual 2003, Volume 18, pages 139-208. The MIT Press. 


\section{A Appendix}

In the paper we use a fixed effects linear estimator to document extrapolation and over-extrapolation. We now test the robustness of these results using several alternative estimators.

Tables 11 and 12 study, respectively, extrapolation and over-extrapolation using alternative estimators. For our results to be robust, we would have to find a positive and significant coefficient when regressing expected income or expectation errors on past income.

In columns 1, we use the mean group (MG) estimator (Pesaran and Smith, 1995). We run the following regression: $y_{i t}=x_{i t} \beta_{i}+u_{i t}$, where $y_{i t}$ is either the expectation or the expectation error of household $i$ at period $t, x$ is the past income, and $u$ is an error term. In the tables, we report the average effect $\hat{\beta}=\sum_{i} \widehat{\beta}_{i} / N$, where $N$ is the number of households.

In columns 2, we use the fixed effects linear estimator with individual slopes (FEIS) to estimate the $\beta$ of this regression: $y_{i t}=\alpha_{1 i}+\alpha_{2 i} t+\gamma_{t}+x_{i t} \beta+u_{i t}$ (Brüderl and Ludwig, 2015).

We are not aware of any estimator that is able to deal with individual fixed effects in a nonlinear model without correcting for the the incidental parameter problem. See Fernández-Val and Weidner (2016) for the case when both $\mathrm{T}$ and $\mathrm{N}$ are large. We instead resort to standard ordered probit and logit models and address the individual unobserved heterogeneity with the individual average value of the dependent variable (expected income or expectation error) and the independent variable (past income) as proxies for the individual fixed effects. $\mathrm{N}$ and $\mathrm{T}$ are large enough to reduce the consistency bias. Columns 3 and 4 report the estimates of the ordered probit (logit) model.

Columns 5 and 6 report the estimates of two panel conditional ordered logit models. The Chamberlain's estimates of fixed effect binary logit models, $\beta^{k}$, are computed at different cutoffs $k$ of the dependent variable. We estimates an average $\beta$ following the blow-up and cluster $(\mathrm{BuC})$ procedure (Baetschmann et al., 2015) and the Das and van Soest (DvS) two-step procedure (Das and van Soest, 1997). Columns 5 and 6 report the results of, respectively, the BuC and DvS estimators. 
The results suggest that extrapolation and over-extrapolation are robust to the use of alternative estimators. The coefficients indeed remain positive and significant in all specifications.

Table 11: Expected income and past income - Alternative estimators

\begin{tabular}{|c|c|c|c|c|c|c|}
\hline VARIABLES & $\begin{array}{c}(1) \\
\text { MG } \\
\text { Exp Income }\end{array}$ & $\begin{array}{c}(2) \\
\text { FEIS } \\
\text { Exp Income }\end{array}$ & $\begin{array}{c}(3) \\
\text { oprobit } \\
\text { Exp Income }\end{array}$ & $\begin{array}{c}(4) \\
\text { ologit } \\
\text { Exp Income }\end{array}$ & $\begin{array}{c}\text { (5) } \\
\text { BuC } \\
\text { Exp Income }\end{array}$ & $\begin{array}{c}\text { (6) } \\
\text { DvS } \\
\text { Exp Income }\end{array}$ \\
\hline Past Income & $\begin{array}{l}0.271^{* * *} \\
(0.0293)\end{array}$ & $\begin{array}{l}0.275^{* * *} \\
(0.0101)\end{array}$ & $\begin{array}{l}0.595^{* * *} \\
(0.0208)\end{array}$ & $\begin{array}{l}1.190^{* * *} \\
(0.0382)\end{array}$ & $\begin{array}{l}0.868^{* * *} \\
(0.0327)\end{array}$ & $\begin{array}{l}0.862^{* * *} \\
(0.0303)\end{array}$ \\
\hline Exp Income (mean) & & & $\begin{array}{l}1.985^{* * *} \\
(0.0198)\end{array}$ & $\begin{array}{l}3.723^{* * *} \\
(0.0383)\end{array}$ & & \\
\hline Past Income (mean) & & & $\begin{array}{c}-0.583^{* * * *} \\
(0.0216)\end{array}$ & $\begin{array}{c}-1.158^{* * *} \\
(0.0392)\end{array}$ & & \\
\hline Constant & $\begin{array}{c}0.108 \\
(0.929)\end{array}$ & & & & & \\
\hline Observations & 31,478 & 31,478 & 32,735 & 32,735 & 52,166 & 29,730 \\
\hline Number of Households & 3,434 & 3,434 & 4,284 & 4,284 & 3,289 & 3,229 \\
\hline IND FE - constant & Yes & Yes & No & No & Yes & Yes \\
\hline IND FE - slope & No & Yes & No & No & No & No \\
\hline TIME FE & No & Yes & Yes & Yes & Yes & No \\
\hline
\end{tabular}

MG refers to the Mean Group estimator, FEIS to Fixed Effects with Individual Slopes, oprobit to ordered probit, ologit to ordered logit, $\mathrm{BuC}$ to blow-up and cluster, DvS to Das and van Soest. Robust standard errors in parentheses. ${ }^{* * *}$ $\mathrm{p}<0.01,{ }^{* *} \mathrm{p}<0.05,{ }^{*} \mathrm{p}<0.1$.

Table 12: Expectation errors and past income - Alternative estimators

\begin{tabular}{|c|c|c|c|c|c|c|}
\hline VARIABLES & $\begin{array}{c}(1) \\
\text { MG } \\
\text { Exp Error }\end{array}$ & $\begin{array}{c}(2) \\
\text { FEIS } \\
\text { Exp Error }\end{array}$ & $\begin{array}{c}\text { (3) } \\
\text { oprobit } \\
\text { Exp Error }\end{array}$ & $\begin{array}{c}(4) \\
\text { ologit } \\
\text { Exp Error }\end{array}$ & $\begin{array}{c}(5) \\
\text { BuC } \\
\text { Exp Error }\end{array}$ & $\begin{array}{c}\text { (6) } \\
\text { DvS } \\
\text { Exp Error }\end{array}$ \\
\hline Past Income & $\begin{array}{l}0.381^{* * *} \\
(0.0900)\end{array}$ & $\begin{array}{l}0.415^{* * *} \\
(0.0130)\end{array}$ & $\begin{array}{l}0.448^{* * *} \\
(0.0175)\end{array}$ & $\begin{array}{l}0.863^{* * *} \\
(0.0322)\end{array}$ & $\begin{array}{l}0.684^{* * *} \\
(0.0292)\end{array}$ & $\begin{array}{l}0.762^{* * *} \\
(0.0280)\end{array}$ \\
\hline Exp Error (mean) & & & $\begin{array}{l}1.388^{* * *} \\
(0.0150)\end{array}$ & $\begin{array}{l}2.594^{* * * *} \\
(0.0282)\end{array}$ & & \\
\hline Past Income (mean) & & & $\begin{array}{c}-0.459^{* * *} \\
(0.0179)\end{array}$ & $\begin{array}{c}-0.884^{* * *} \\
(0.0333)\end{array}$ & & \\
\hline Constant & $\begin{array}{l}-9.825 \\
(10.59)\end{array}$ & & & & & \\
\hline Observations & 23,452 & 23,452 & 24,446 & 24,446 & 50,896 & 22,608 \\
\hline Number of Households & 2,805 & 2,805 & 3476 & 3476 & 2772 & 2772 \\
\hline IND FE - constant & Yes & Yes & No & No & Yes & Yes \\
\hline IND FE - slope & No & Yes & No & No & No & No \\
\hline TIME FE & No & Yes & Yes & Yes & Yes & No \\
\hline
\end{tabular}

MG refers to the Mean Group estimator, FEIS to Fixed Effects with Individual Slopes, oprobit to ordered probit, ologit to ordered logit, $\mathrm{BuC}$ to blow-up and cluster, DvS to Das and van Soest. Robust standard errors in parentheses. ${ }^{* * *}$ $\mathrm{p}<0.01,{ }^{* *} \mathrm{p}<0.05,{ }^{*} \mathrm{p}<0.1$. 


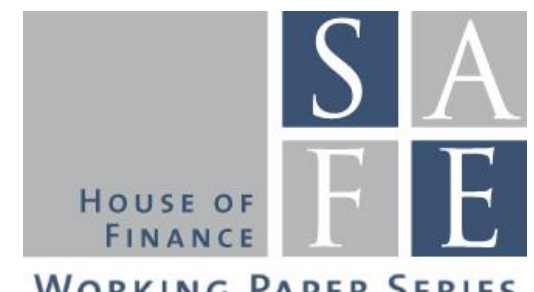

WORKING PAPER SERIES

\section{Recent Issues}

No. 232 Jannic Alexander Cutura

No. 231 Benjamin Clapham, Peter Gomber, Jens Lausen, Sven Panz

No. 230 Yalin Gündüz, Giorgio Ottonello, Loriana Pelizzon, Michael

Schneider, Marti G.

Subrahmanyam

No. 229 Daniel Harenberg

No. 228 Roberto C. Panzica

No. 227 Mila Getmansky, Ravi Jagannathan, Loriana Pelizzon, Ernst Schaumburg, Darya Yuferova

No. 226 Loriana Pelizzon, Marti G. Subrahmanyam, Davide Tomio, Jun Uno

No. 225 Monica Billio, Massimiliano Caporin, Lorenzo Frattarolo, Loriana Pelizzon

No. 224 Giulio Girardi, Kathleen W. Hanley, Stanislava Nikolova, Loriana Pelizzon, Mila Getmansky Sherman

No. 223 Florian Deuflhard

No. 222 Vanessa Endrejat, Matthias Thiemann

No. 221 Axel H. Börsch-Supan, Klaus Härtl, Duarte N. Leite, Alexander Ludwig
Debt Holder Monitoring and Implicit Guarantees: Did the BRRD Improve Market Discipline?

Liquidity Provider Incentives in Fragmented Securities Markets

Lighting up the Dark: Liquidity in the German Corporate Bond Market

Asset Pricing in OLG Economies With Borrowing Constraints and Idiosyncratic Income Risk

Idiosyncratic Volatility Puzzle: The Role of Assets' Interconnections

Stock Price Crashes: Role of Slow-Moving Capital

Central Bank-Driven Mispricing?

Networks in risk spillovers:

A multivariate GARCH perspective

Portfolio Similarity and Asset Liquidation in the Insurance Industry

Quantifying Inertia in Retail Deposit Markets

Reviving the Shadow Banking Chain in Europe: Regulatory Agency, Technical Complexity and the Dynamics of CoHabitation

Endogenous Retirement Behavior of Heterogeneous Households Under Pension Reforms 